\title{
Human Rights Accountability of Transnational Corporations: A Potential Response from Bilateral Investment Treaties
}

\section{Jun Zhao*}

The Impact of transnational corporations' activities on local communities and populations can result in violations of human rights. There are compelling reasons to hold TNCs liable for human rights violations. The regulation of TNCs has become a global public good, and joint forces are needed to hold TNCs more accountable for their violations of human rights. Bilateral Investment Treaties, as a main component of international investment law regulating international investment activities, require urgent reform in this area. This article examines why and how BITs could be drafted or amended in order to enhance TNCs' human rights accountability. After taking stock of existing legal institutions regulating TNCs, this article analyzes the difficulties and hurdles in subjecting TNCs to human rights liability. Finally, this article probes into potential advisable proposals on how BITs should be reformed, both in substance and procedure, to better respect human rights.

\section{Keywords}

Transnational Corporations, Human Rights, Bilateral Investment Treaties

* Professor of Zhejiang University Guanghua Law School. LL.B.(Zhejiang), J.D.(Cornell), LL.M.(Harvard). ORCID: http://orcid.org/0000-0003-2124-9262. The author extends the deepest appreciation to Professors Saul Levmore, Professor Tom Ginsburg, Professor Virginia Harper Ho, Mr. Jim Gao, Professor J. Ashley Roach and Assistant Professor Jamie Edwards, for their invaluable help across several drafts. Sincere thanks also goes to Ms. Wei Zhao for her research assistance. The author may be contacted at: junzhao@zju.edu.cn / Address: 51 Zhijiang Road, Hangzhou, Zhejiang Province 310008 P.R. China. 


\section{Introduction}

In the modern globalized system, transnational corporations ("TNCs") have been rising in economic, social, and political importance. ${ }^{1}$ Recently, there has been a growing body of evidence that the impact of TNCs' activities in developing countries can result in violations of human rights or act as a catalyst for violation of human rights. ${ }^{2}$ E.g., TNCs' doing business in the developing world were not only involved in various conflicts, but were in fact the engine of the conflicts. ${ }^{3}$ Many TNCs have been accused of violating their workers' rights to just and favorable working conditions such as suppressing trade unions, denying workers' right to organize, and causing environmental disasters. ${ }^{4}$

Human rights abuses by foreign corporations are well documented. As Dumberry and Dumas-Aubin succinctly summarized, TNCs have been accused of violating the right to enjoy life, to freedom from torture and cruel, inhuman, or degrading treatment, to freedom from slavery and arbitrary imprisonment, and many other human rights. ${ }^{5}$

As per the Report of the Special Representative of the Secretary-General on the issue of human rights and transnational corporations and other business enterprises, the Corporations are alleged to have impacted the full range of human rights (Annex

1 See generally J. Ruggie, Special Representative of the UN Secretary-General on the Issue of Human Rights and Transnational Corporations and Other Business Enterprises, Guiding Principles on Business and Human Rights: Implementing the United Nations "Protect, Respect and Remedy" Framework ("SRSG"), U.N. Doc. A/HRC/17/31 (Mar. 21, 2011), available at http://www.ohchr.org/Documents/Publications/GuidingPrinciplesBusinessHR_EN.pdf (last visited on Apr. 13, 2015).

2 Deriving from respect for human dignity, human rights of individuals are usually defined as a normative embodiment of the most important universal values of human beings, applicable in every human community. Even though the exact definition of what constitutes fundamental human right is difficult to define and variations occur in the literature, minimum fundamental human rights, which corporations are required to observe, has been catalogued into three groups by certain scholars. These include fundamental human rights preserving the security of persons, labor rights, and non-discrimination. For details, see N. Jägers, Corporate Human Rights Obligations: In Search of Accountability (2002); J. Cernic, Corporate Human Rights Obligations at the International Level, 16 WilLamette J. INT'L L. \& Disp. Resol. 130-4 (2008).

3 See Report of the Panel of Experts on the Illegal Exploitation of Natural Resources and Other Forms of Wealth of the Democratic Republic of Congo, U.N. Doc. S/2001/357 (Apr. 12, 2001), available at http://www.securitycouncilreport. org/atf/cf/\%7B65BFCF9B-6D27-4E9C-8CD3-CF6E4FF96FF9\%7D/DRC\%20S\%202001\%20357.pdf (last visited on Apr. 14, 2015).

4 R.-C. Drouin, Promoting Fundamental Labor Rights through International Framework Agreements: Practical Outcomes and Present Challenges, 31 Comp. LAB. L. \& PoL'y J. 591(2010).

5 P. Dumberry \& G. Dumas-Aubin, A Few Pragmatic Observations on How BITs Should be Modified to Incorporate Human Rights Obligations, 11 Transnat. DisP. MgM't 1 (2014), available at http://ssrn.com/abstract=2531084 (last visited on Apr. 13, 2015). 